\title{
Host surface tissues and basidiospore-derived infection strate- gies of some rust fungi
}

\author{
Longo Nicola*, Biancamaria Naldini, Ambretta Cecchi Fiordi, Gabriele Tani and \\ Pietro Di FAlco
}

Dipartimento di Biologia Vegetale, Laboratorio di Botanica Generale, Università di Firenze, Via La Pira 4, 50121 Firenze - Italy.

\begin{abstract}
Some Authors belief that the basidiospore germ tubes of rust fungi penetrate angiosperms directly and gymnosperms indirectly, hypothesizing that the different strategies of basidiospore-derived penetrations could be ascribed to the heavily cutinized and thick walled epidermal cells of the leaves of gymnosperms. In this paper the surface tissues of the organs of some angiosperms and gymnosperms - which are directly and/or indirectly penetrated by basidiospore germlings of Melampsora spp., Cronartium flaccidum and Crysomyxa abietis - were examined, in order to: (i) evaluate the role of the cuticular and epidermal cell-wall thickness, still considered a barrier to a direct penetration, and (ii) search for other possible cyto-histological aspects of surface tissues which could explain the different penetration strategies of rust basidiospore germlings. The results show that the thickness of cuticle and epidermal cell walls of the organs onto which the monokaryotic phase of each rust species has fitted itself during evolution to penetrate is not important in determining the penetration strategy, whereas it seems that it is the presence of lignin in the surface tissues of these organs which probably limits the direct penetration of rust basidiospore germlings.
\end{abstract}

Key words: Basidiospore-derived infection, Cronartium, host surface tissues, Melampsora, rust fungi.

\section{INTRODUCTION}

Spore germ tubes of rust fungi use two ways of penetration to infect the organs of their hosts: (i) directly through the intact wall of the epidermal cell, which is the characteristic way of the monokaryotic phase, i.e. basidiospore-derived penetration; (ii) indirectly through the stomatal apertures, which is the characteristic way of the dikaryotic phase, i.e. aeciospore - and urediniospore-derived penetration. As a result of a direct penetration an intraepidermal infection structure develops, whereas an indirect penetration produces a substomatal infection structure (LiTTLEFIELD and Heath 1979; Bushnell and RoeLFS 1984; Hoch and Staples 1991; Mendgen et al. 1996; Epstein and Nicholson 1997; MendGEN 1997).

However, Patton and Johnson (1970) and Bergdhal and French (1985) reported that the penetration of the basidiospore germlings of $\mathrm{Cro}^{-}$ nartium ribicola J.C. Fisher ex Rabenh. on Pinus

\footnotetext{
* Corresponding author: phone + 39 2757395/399; fax +392757398; e-mail: nlongo@unifi.it
}

strobus L. and of Cronartium comandrae Pk. on Pinus banksiana Lamb. occurred indirectly through the stomatal apertures, despite the fact that it involved basidiospore-derived infections. Moreover, many studies (Miller et al. 1980; Gray et al. 1983; Gold and Mendgen 1984; 1991; Hopkin et al.1988; LoNGO et al. 1988; 1991; 1994; 1997; Morin et al. 1992) confirmed the direct penetration of the basidiospore germ tubes of several rust fungi on their hosts, and considered the indirect penetration of basidiospore germlings of $C$. ribicola and C. comandrae peculiar events which needed to be clarified.

Gold and Mendgen (1984), referring to two other cases of basidiospore-derived indirect penetration, i.e. Crysomyxa abietis (Wallr.) Unger on Picea abies L. (GriLl et al. 1978) and Coleosporium spp. on Pinus spp. (BAUER 1983), hypothesized that the different strategies associated with basidiospore-derived penetrations - direct on angiosperms and indirect on gymnosperms - could be ascribed to the heavily cutinized and thick walled epidermal cells of the leaves of gymnosperms.

In point of fact, Longo et al. (1994), in their studies on the monokaryotic phase of Melampsora pulcherrima (Bub.) Maire on Mercurialis annua L., 
reported a direct basidiospore-derived penetration on the leaves of this angiosperm. On the other hand, Longo et al. (1988; 1991; 1997), studying the basidiospore-derived penetration of Melampsora pinitorqua (A. Br.) Rostr. on cotyledons and primary needles of Pinus pinea L., as well as on growing shoots of Pinus sylvestris L., and of Melampsora larici-tremulae Kleb. on growing needles from brachiblasts of Larix decidua Mill., observed that these two rust fungi directly penetrated these gymnosperms. A direct basidiospore-derived penetration was described also for Cronartium quercuum (Berk.) Miyabe ex Shirai f.sp. fusiforme (Cumm.) Burds. \& Snow on hipocotyls, cotyledons and primary needles of $P i$ nus elliottii Engelm. var. elliottii (Miller et al. 1980) and for Endocronartium harknessi (J.P. Moore) Y.Hyrat. on hipocotyls and cotyledons of Pinus contorta Dougl. var. latifolia Englm. (HopKIN et al. 1988).

Such a behaviour on gymnosperms was confirmed by Longo et al. (1997), MoricCa et al. (2003) and RAgAzZI et al. (2005). Indeed, owing to the partial overlapping of the host range of $M$. pinitorqua and M. larici-tremulae described in previous works by LoNGo et al. $(1970 ; 1975)$, a basidiospore-derived direct penetration was shown also in the following cases of inoculations: 1) $M$. larici-tremulae on growing shoots of $P$. sylvestris (LoNGo et al. 1997); 2) M. pinitorqua on growing needles from brachiblasts of Larix decidua (MorICCA et al. 2003); 3) M. larici-tremulae on cotyledons and primary needles of $P$. pinea (MoricCA et al. 2003).

On the other hand, Longo et al. (1991) emphasized that the indirect basidiospore-derived penetration on gymnosperms, described by PATTON and Johnson (1970) for basidiospore germlings of C. ribicola on P. strobus, takes place on organs whose surface tissues have different cytological characteristics, i.e. not only on secondary needles but also on primary needles and cotyledons.

One other case of indirect basidiospore-derived penetration on gymnosperms was proposed by RAgazzi et al. (1987) and RAgazzi and DelLAVALLE FEDI (1992) after some observations on basidiospore germlings of Cronartium flaccidum (Alb. et Schw.) Wint. on the surface of cotyledons, primary and secondary needles of Pinus pinaster Ait. and Pinus nigra Arn. subsp. laricio (Poiret) Maire. More recently, Longo et al. (2000) demonstrated that the basidiospore-derived penetration of C. flaccidum on Pinus pinea was effectively indirect through the stomata, giving rise to a substomatal infection structure on all types of host needles.

From all these reports it can be seen that the same gymnosperm organs - see cotyledons and primary needles - are penetrated directly or indirectly by basidiospore germlings depending on the rust species; this behaviour probably depends on the rust species' mode of penetration into gymnosperm organs usually infected in nature: i.e., i) a direct penetration by M. pinitorqua, C. quercuum f.sp. fusiforme and $E$. harknessii on pine primary tissues (hypocotils, cotyledons, stems and primary needles) and by $M$. larici-tremulae on growing needles from brachiblasts of Larix decidua; ii) an indirect penetration by C. ribicola, C. comandrae, C. flaccidum and Coleosporium spp. on pine secondary needles, and by Crysomyxa abietis on Picea abies growing needles. Hence, Longo et al. (2000) supposed that the reason for the dynamics of indirect penetration carried out by some rust fungi in the monokaryotic phase could be as follows. The rust fungi which evolved to infect "in nature" organs with some surface cyto-histological characteristics, such as the heavily cutinized and thick walled epidermal cells of the secondary needles of Pinus spp., could be prevented from exercising a suitable mechanical and/or enzymatic action. Consequently, in order to fit themselves onto a substratum with the above characteristics, it would be necessary for the basidiospore germlings to modify their way of penetration from the direct one, which is typical of the rust monokaryotic phase, to that of the indirect type. Notwithstanding, Longo et al. (2000) observed that the morpho-functional characteristics of the penetration structures of C.flaccidum remained those of a monokaryotic phase, even if this indirect penetration recalled the mode of penetration (through the stomatal aperture) of a dikaryon.

The aims of this work are: (i) to examine the surface tissues of organs directly and/or indirectly penetrated by some of the above cited rust fungi in the monokaryotic phase, in order to evaluate the role of the cuticular and epidermal cell wall thickness, still considered in literature as a barrier to a direct penetration, and (ii) to search for other possible cyto-histological aspects of surface tissues which could explain the different penetration strategies of basidiospore germlings.

\section{MATERIALS AND METHODS}

The organs susceptible to be penetrated in nature and/or after artificial inoculations by basid- 
iospore germlings of the rust fungi Melampsora pulcherrima, M. larici-tremulae, M. pinitorqua, Cronartium flaccidum and Crysomyxa abietis were studied, namely:

- leaves of Mercurialis annua;

- growing needles from brachiblasts of Larix decidua;

- growing shoots of Pinus sylvestris;

- cotyledons and primary needles of Pinus pinea;

- growing and grown-up secondary needles of Pinus pinea;

- growing needles of Picea abies.

The following characters of surface tissues were considered.

For the epidermis:

- cuticularization;

- thickness and cutinization of the cell-walls;

- amount of cytoplasm in the cells;

- absence or presence of lignin in the cell walls.

For the hypodermis:

- absence or presence of layers and their number;

- absence or presence of lignin in the cell walls.

Small fragments from the samplings were sectioned using an American optical cryo-cut microtome and treated using the methods hereafter referred to. In order to highlight the cutin, the sections where treated: 1 ) with Nile-Red (GrEENSPAN et al. 1985) $0,01 \%$ in acetone for 5 minutes, and observed using epifluorescence optics with Blue light exciter filter BP 450-490 nm, dichroic beam splitter RKP $510 \mathrm{~nm}$ and barrier filter LP $520 \mathrm{~nm}$; 2) with an 1:1 mixture of Fluorol-yellow 088 $0,01 \%$ in polyethylene glycol Wt 400 and glycerol $90 \%$ in distilled water (BRUNDRETT et al. 1991), for 1 hour; in this case the sections were observed using epifluorescence optics with UV light exciter filter BP 360-480 nm, dichroic beam splitter RKP $400 \mathrm{~nm}$ and barrier filter LP $430 \mathrm{~nm}$. In order to highlight the lignin, the sections where treated with the Phloroglucinol test (Phloroglucinol in $\mathrm{HCl}$ 20\%) (JoHANSEN 1940).

All observations were made using Leitz Orthoplan and Leica DMRB Fluo microscopes.

\section{RESULTS}

The data obtained from the observations were summarized in Table 1. For each organ and host species examined, the rust species and its penetration strategy (as described in previous observa- tions and considered in the Introduction) are listed in the third column of the Table.

The leaves of Mercurialis annua (Fig. 1- a, b, c), the growing needles from brachiblasts of Larix decidua (Fig. 1- d, e, f), the growing shoots of P. sylvestris (Fig. 1 - g, h, i), as well as the cotyledons and primary needles of $P$. pinea (Fig. $1-1, \mathrm{~m}, \mathrm{n}$ and $o, p, q$ respectively) - all of wich are organs which are directly penetrated - have the following characteristics:

- highly visible cuticle; the cuticle appears thicker in the growing needles of L. decidua (Fig. 1 - d, e) and growing shoots of P. sylvestris (Fig. 1 $\mathrm{g}, \mathrm{h}$ );

- thin-walled epidermal cells;

- abundant cytoplasm in epidermal cells;

- absence of lignin in epidermal cell walls;

- absence of hypoderm.

The growing and grown-up secondary needles of $P$. pinea (Fig. 2 - a, b, c and d, e, f respectively) i.e., organs which are indirectly penetrated, have the following characteristics:

- highly visible cuticle; the cuticle, in both types of secondary needles (Fig. $2-\mathrm{a}, \mathrm{b}$ and d, e), appears as thick as in L.decidua needles and P. sylvestris shoots;

- thick walled epidermal cells;

- scarce cytoplasm in epidermal cells;

- cutinization of the radial and inner tangential walls of the epidermal cells (Fig. 2 - a, b and $\mathrm{d}, \mathrm{e})$;

- presence of hypoderm, mono-layered in the growing needles (Fig. 2 - c) and bi-layered in grown-up ones (Fig. 2 - f), with lignified cell walls; specifically, the presence of lignin was noted in the cell walls of the first layer of hypoderm, and also appeared to interest the inner tangential wall and partially the radial walls of the epidermal cells.

The growing needles of Picea abies (Fig 2 - g, $h, i)$ - which are indirectly penetrated in the same manner as the secondary needles of $P$. pinea - have the following characteristics:

- highly visible cuticle; the cuticle appears thin (Fig. 2 - g, h) as in the leaves of M. annua and cotyledons and primary needles of $P$. pinea;

- epidermal cells with slightly thickened walls;

- well visible cytoplasm in epidermal cells;

- presence of mono-layered hypoderm (Fig. 2

- i) with lignified cell walls; the localization of lignin in the surface tissues appears as that in secondary needles of $P$. pinea.

It must be noted that the thickness of cuticle and cell walls, and the amount of cytoplasm of the 
Table 1 - Characteristics observed in the surface tissues of organs susceptible to be penetrated by the considered rust species, and basidiospore-derived penetration strategies of the rust species. 1, 2, 3 indicate increasing values approximately estimated; +, - indicate presence or absence.

\begin{tabular}{|c|c|c|c|c|c|c|c|c|c|}
\hline \multirow{3}{*}{$\begin{array}{c}\text { host } \\
\text { species }\end{array}$} & \multirow{3}{*}{$\begin{array}{l}\text { organs } \\
\text { leaves }\end{array}$} & \multirow{2}{*}{\multicolumn{2}{|c|}{$\begin{array}{l}\text { rust species / } \\
\text { penetration strategy }\end{array}$}} & \multicolumn{4}{|c|}{ epidermis } & \multicolumn{2}{|c|}{ hypodermis } \\
\hline & & & & \multirow{2}{*}{$\begin{array}{c}\begin{array}{c}\text { cuticle } \\
\text { thickness }\end{array} \\
1\end{array}$} & \multirow{2}{*}{$\begin{array}{c}\begin{array}{c}\text { wall } \\
\text { thickness }\end{array} \\
1\end{array}$} & \multirow{2}{*}{$\begin{array}{c}\begin{array}{c}\text { walls } \\
\text { cutinized }\end{array} \\
-\end{array}$} & \multirow{2}{*}{$\begin{array}{c}\begin{array}{c}\text { cytoplasm } \\
\text { amount }\end{array} \\
3\end{array}$} & \multirow{2}{*}{$\begin{array}{c}\begin{array}{c}\text { layer } \\
\text { number }\end{array} \\
-\end{array}$} & \multirow{2}{*}{$\frac{\text { lignin }}{-}$} \\
\hline & & $\begin{array}{l}\text { Melampsora } \\
\text { pulcherrima }\end{array}$ & direct & & & & & & \\
\hline Larix & growing & $\begin{array}{l}\text { Melampsora } \\
\text { larici-tremulae }\end{array}$ & direct & 2 & 1 & - & 3 & - & - \\
\hline decidua & needles & $\begin{array}{l}\text { Melampsora } \\
\text { pinitorqua }\end{array}$ & direct & 2 & 1 & - & & - & - \\
\hline \multirow{3}{*}{$\begin{array}{l}\text { Pinus } \\
\text { sylvestris }\end{array}$} & \multirow{2}{*}{$\begin{array}{l}\text { growing } \\
\text { shoots }\end{array}$} & $\begin{array}{l}\text { Melampsora } \\
\text { pinitorqua }\end{array}$ & direct & \multirow{2}{*}{2} & \multirow{2}{*}{1} & \multirow{2}{*}{-} & \multirow{2}{*}{3} & \multirow{2}{*}{-} & \multirow{2}{*}{ - } \\
\hline & & $\begin{array}{l}\text { Melampsora } \\
\text { larici-tremulae }\end{array}$ & direct & & & & & & \\
\hline & & $\begin{array}{l}\text { Melampsora } \\
\text { pinitorqua }\end{array}$ & direct & & & & & & \\
\hline \multirow[t]{3}{*}{$\begin{array}{l}\text { Pinus } \\
\text { pinea }\end{array}$} & cotyledons & $\begin{array}{l}\text { Melampsora } \\
\text { larici-tremulae }\end{array}$ & direct & 1 & 1 & - & 3 & - & - \\
\hline & & $\begin{array}{l}\text { Cronartium } \\
\text { flaccidum }\end{array}$ & indirect & & & & & & \\
\hline & & $\begin{array}{l}\text { Melampsora } \\
\text { pinitorqua }\end{array}$ & direct & & & & & & \\
\hline \multirow[t]{2}{*}{$\begin{array}{l}\text { Pinus } \\
\text { pinea }\end{array}$} & $\begin{array}{l}\text { primary } \\
\text { needles }\end{array}$ & $\begin{array}{l}\text { Melampsora } \\
\text { larici-tremulae }\end{array}$ & direct & 1 & 1 & - & 3 & - & - \\
\hline & & $\begin{array}{l}\text { Cronartium } \\
\text { flaccidum }\end{array}$ & indirect & & & & & & \\
\hline $\begin{array}{l}\text { Pinus } \\
\text { pinea }\end{array}$ & $\begin{array}{l}\text { growing } \\
\text { secondary } \\
\text { needles }\end{array}$ & $\begin{array}{l}\text { Cronartium } \\
\text { flaccidum }\end{array}$ & indirect & 2 & 3 & + & 1 & one & + \\
\hline $\begin{array}{l}\text { Pinus } \\
\text { pinea }\end{array}$ & $\begin{array}{l}\text { grown-up } \\
\text { secondary } \\
\text { needles }\end{array}$ & $\begin{array}{l}\text { Cronartium } \\
\text { flaccidum }\end{array}$ & indirect & 2 & 3 & + & 1 & two & + \\
\hline $\begin{array}{l}\text { Picea } \\
\text { abies }\end{array}$ & $\begin{array}{l}\text { growing } \\
\text { needles }\end{array}$ & $\begin{array}{l}\text { Crysomyxa } \\
\text { abietis }\end{array}$ & indirect & 1 & 2 & - & 2 & one & + \\
\hline
\end{tabular}

host organs were approximately estimated, since there were no measurements related to the observations.

\section{DISCUSSION}

The cyto-histological aspects observed in the surface tissues of host organs susceptible to be penetrated by the considered rusts allow some remarks: $i$ ) The cuticle appears thicker in the growing shoots of $P$. sylvestris, growing needles of Larix decidua, and growing and grown-up secondary needles of $P$. pinea than in the other organs examined. ii) The epidermal cells in both types of secondary needles of $P$. pinea, unlike the other or- gans, are poor in cytoplasm and show thick cutinized walls. iii) A hypoderm with lignified cell walls is present only in both types of secondary needles of $P$. pinea and in growing needles of $P$. abies. The results are interesting to evaluate an estimable involvement of the above described characteristics of host surface tissues in relation to rust penetration strategies.

Cuticle and epidermal cell walls - As reported in the Introduction, some Authors maintain that, in host-parasite interactions, the parasite penetration strategy could change from direct to indirect as a consequence of the thickness of the cuticle and epidermal cell walls of host organs which are considered as a barrier to a direct penetration 


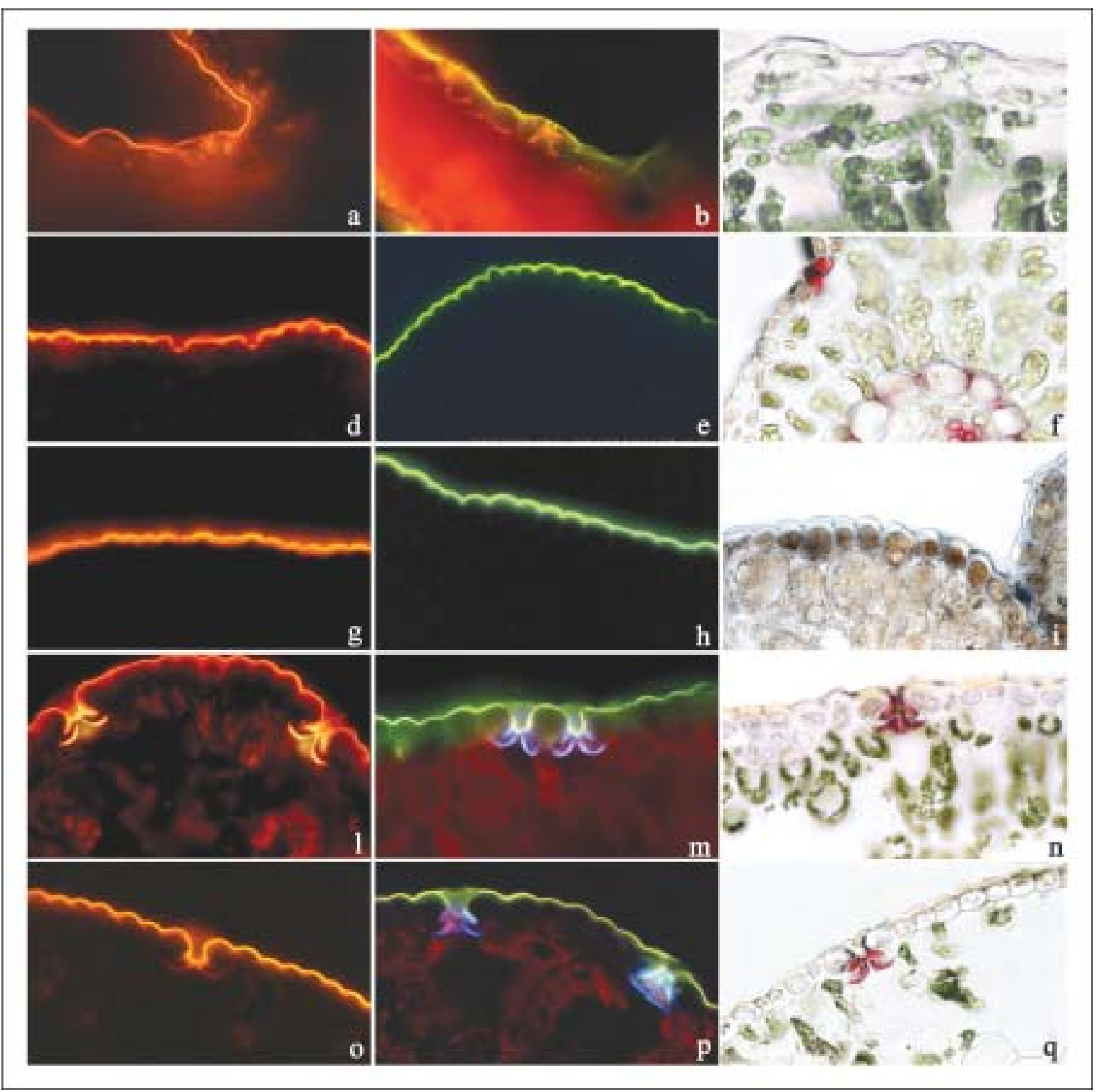

Fig. 1 - Leaves of Mercurialis annua (a, b, c); growing needles from brachiblasts of Larix decidua (d, e, f); growing shoots of Pinus sylvestris ( $\mathrm{g}, \mathrm{h}, \mathrm{i})$; cotyledons $(\mathrm{l}, \mathrm{m}, \mathrm{n})$ and primary needles $(\mathrm{o}, \mathrm{p}, \mathrm{q})$ of Pinus pinea. Transverse sections. The cutin is shown with Nil-Red $(\mathrm{a}, \mathrm{d}, \mathrm{g}, \mathrm{l}, \mathrm{o})$ and Fluorol-yellow $(\mathrm{b}, \mathrm{e}, \mathrm{h}, \mathrm{m}, \mathrm{p})$. The lignin is shown with Phloroglucinol test (c, f, i, n, q). The cuticle appears thicker in the needles of L. decidua (d, e) and shoots of P. sylvestris (g, $\mathrm{h})$. The lignin is present only at the level of the stomata in the needles of $L$. decidua (f), cotyledons (n) and primary needles (q) of P. sylvestris, and vein of L. decidua (f). All pictures 200x.

(CAmpbell 1972; Diner and MotT 1982; Gold and Mendgen 1984).

With regard to this problem of plant pathogenesis, it is necessary to keep in mind that the role of fungal enzymes in degrading the surface tissues of host organs to be penetrated is clearly acknowledged. In reality, the lythic enzymes which are commonly reported by Authors - cutinases, pectinases, hemicellulases, cellulases - carry out their activity on fatty substances such as cutin and on polysaccharides/compounds which characterize the plant cell wall (TEN HAve et al. 2002). The production of fungal enzymes is induced by exchange at cuticular level of signals which regulate the host-parasite interaction, e.g., the penetration of host surface (HocH and STAPLes 1991; Chassot and Métraux 2005).

It must be remembered that in direct penetration typical of the rust monokaryotic phase, the role played by the enzymatic power together with 


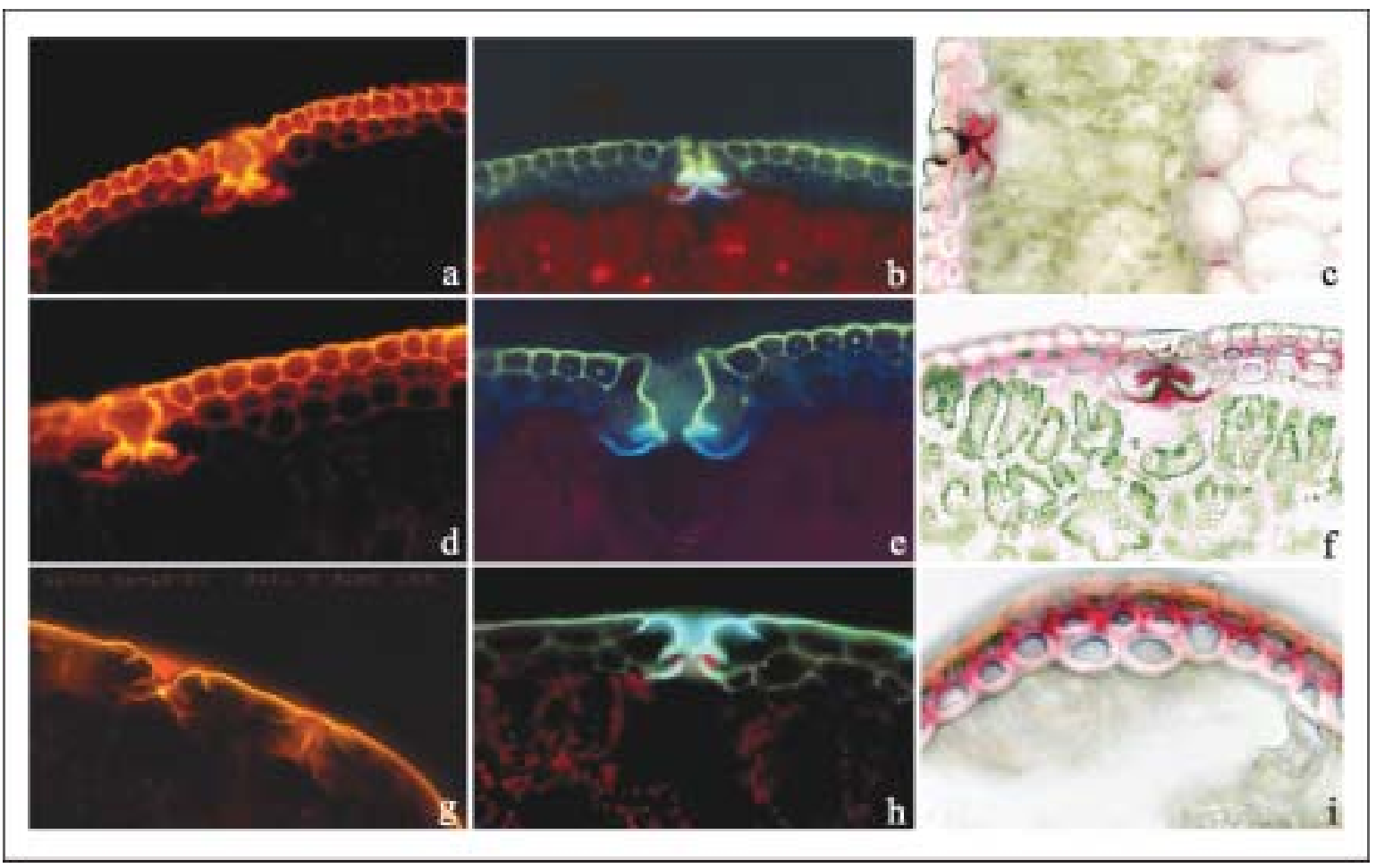

Fig. 2 - Growing (a, b, c) and grown-up (d, e, f) nedlees of Pinus pinea; growing needles of Picea abies (g, h, i). Transverse sections. The cutin is shown with Nil-Red ( $, \mathrm{d}, \mathrm{g})$ and Fluorol-yellow (b, e, h). The lignin is shown with Phloroglucinol test $(\mathrm{c}, \mathrm{f}, \mathrm{i})$. The cuticle appears thicker in growing $(\mathrm{a}, \mathrm{b})$ and grown-up $(\mathrm{d}, \mathrm{e})$ nedlees of $P$. pinea. Note the presence of lignin in the surface tissues of growing (c), grown-up (f) needles of P. pinea and needles of Picea abies (i). All pictures 200x.

turgor pressure is very important in the penetration structures which are involved in host-rust interaction.

As regards the role of cell wall degrading enzymes in fungi with elaborate and melanised appressoria which generate high turgor pressure (such as Colletotrycum and Magnaporte species), WIRsEL et al. (2004) indicate that it is very likely that both, enzymes and force, are needed for initial penetration, the proportion being characteristic of each pathogen. According to GoLD and Mendgen (1991) and Hardham (2001), the extracellular mucilaginous matrix commonly present around rust germlings is useful not only to favour their adhesion to host organs, but above all as an enzymatic reserve - especially cutinase - for penetration. While the turgor pressure inside the appressorium plays a role in direct penetration even if the appressorium is not melanised, the enzymatic action is very important, together with the mechanical one, so as to enable the host cuticle and cell wall to be perforated (MENDGEN and DEISING 1993; MENDGEN et al. 1996; HowARD 1997; Xu HaIXIN et al. 1997). A combination of enzyme activity and mechanical force in the direct host penetration was described also for Erysiphe graminis by PRYCE-Jones et al. (1999). Moreover, Trail and Koller (1990) indicated that leaf-specific pathogens have cutinases with $\mathrm{pH}$ optima which are distinct from those of the stem-pathogens, whereas pathogens that infect both stems and leaves secreted both cutinase types. Thus, there is evidence that the cutinase plays a role in the expression of tissue specificity by directly penetrating fungal pathogens.

Then, if one considers the powerful role of enzymatic action in directly penetrating fungal pathogens described above, one should think that the thickness of cuticle and epidermal cell walls of host organs (either of angiosperms or gymnosperms) does not determine the penetration strategy of basidiospore germlings. That opinion is confirmed by the results of this research (see Table 1).

Indeed, with regard to the influence of the cuticle as a barrier to a direct penetration, one must observe that the basidiospore germlings of $M$. pulcherrima directly penetrate the leaves of $M$. annua, which have a thin cuticle. On the other hand, the basidiospore germlings of $M$. larici-tremulae 
directly penetrate either the growing needles of $L$. decidua or the artificially inoculated growing shoots of nonhost $P$. sylvestris, both of which appear to have a thick cuticle; $M$. larici-tremulae maintains the same penetration strategy on artificially inoculated cotyledons and primary needles of $P$. pinea, which present a thin cuticle. Likewise, the basidiospore germlings of $M$. pinitorqua directly penetrate the growing shoots of $P$. sylvestris, which appear to have a thicker cuticle than that of the cotyledons and primary needles of $P$. pinea, which are directly penetrated also; $M$. pinitorqua too maintains a direct penetration when is inoculated on growing needles of $L$. decidua, which have a thick cuticle.

Amount of cytoplasm in the epidermal cells - Another aspect of the organ surface which could affect the rust penetration strategy is the amount of cytoplasm in the epidermal cells. The protoplast viability, and then the adhesion between the epidermal cell wall and the plasmamembrane, are necessary for the cells to establish the host-parasite relationship, e.g., to determine wall-associated defense responses and consequently the penetration failure (Heath 2002), or the penetration success. The epidermal cells are always retained viable, also where they are characterized by thickened walls and a reduced amount of cytoplasm as in both the secondary needles of Pinus pinea (host organs of Cronartium flaccidum) and, though somewhat less, in the growing needles of Picea abies (host organs of Crysomyxa abietis). Consequently, the needle epidermal cells of both host species, when penetrated, can establish a hostparasite relationship. Since our results show that those organs are in fact indirectly penetrated by their specific rust fungus, also the amount of cytoplasm in the epidermal cells of host organs, as well as the thickness of cuticle and cell walls already mentioned, does not appear to determine the penetration strategy.

All these observations lead one to hypothesize that other cyto-histological aspects of host surface tissues rather than the thickness of cuticle and epidermal cell walls or the amount of cytoplasm in these cells, could be responsible for the indirect penetration carried out on their hosts by Cronartium flaccidum and Crysomyxa abietis in the monokaryotic phase.

Presence of lignin in the surface tissues - It is worth noting that both the secondary needles of Pinus pinea and growing needles of Picea abies, which are indirectly penetrated by their specific rust fun- gus, have a hypodermis which shows clearly lignified cell walls.

According to the literature on the anatomy of conifers, the surface tissues of secondary needles (epidermis and hypodermis) have cells with lignified walls (EsAu 1965). The hypodermis is the tissue which is characteristically interested by lignification, even if the degree of lignification and the tissues which are interested vary according to the different species (NAPP-ZINN 1966). Lignin infiltrates the spaces among the cell wall cellulosic microfibrils, increasing the mechanical strength and decreasing the permeability and degradability of the walls (Aist 1983). Indeed, lignin is a phenolic compound which is not easily degradable by enzymes. Moreover, enzymes such as ligninase are very restricted in their distribution (WALTON 1994) and a ligninase action by strictly biotrophic fungi such as the rusts is unknown.

The lignification process of plant cell walls, either as a natural or induced event, has a special function in the host-parasite interaction. Indeed, where the natural differentiation of cell walls includes lignification, this occurrence may well be a factor in constitutive resistance toward pathogenic fungi. In cell walls which remain unmodified, chiefly in the primary plant body, the evidence for the constitutive resistance of cell wall to penetration is weak and no one component seems to have been clearly implicated (SMART 1991). Again, it is worth remembering the evidence for lignin accumulation during the expression of the induced resistance (AIsT 1983; SOUTHERTON and Deverall 1990). Soukupová et al. (2000), studying the influence of atmospheric pollutans on tissue lignification in needles of Picea abies, emphasized the role of lignified cell walls of the hypodermis in mechanical strength and in resistance to pathogenic attack.

Concluding remarks - Given what has been reported on the role of lignin, it is possible that the cell wall lignification of epidermis and hypodermis in secondary needles of Pinus pinea and in growing needles of Picea abies was responsible for: (i) the inability of basidiospore germlings of Cronartium flaccidum and Crysomyxa abietis to carry out a direct penetration, and (ii) the fitness of these rust fungi during their evolution to an indirect penetration strategy. So much so that, this same strategy is mantained by C. flaccidum also in the organs which are not characterized by surface tissues with lignified cell walls, such as cotyledons and primary needles of Pinus pinea which were artificially inoculated. 
On this subject, it is demonstrated by the observations of this paper that in the surface tissues of organs which are directly penetrated by basidiospore germlings the lignin was never present, at least in the growing period during which these organs are susceptible to rust fungus infection.

Hence, the results show that the thickness of cuticle and epidermal cell walls of organs on which the monokaryotic phase of each rust species has fitted itself to penetrate could not be important in determining the penetration strategy (direct or indirect), whereas it appears that the presence of lignin in the surface tissues of these organs could effectively limit the direct mode of penetration of rust basidiospore germlings.

\section{REFERENCES}

Aist J.R., 1983 - Structural responses as resistance mechanisms. In: Y.A. Bailey and B.J. Deverall (Eds.). "The Dynamics of Host Defence", pp. 33-70. Academic Press.

BAUER R., 1983 - Experimentell - ontogenetische und karyologische Untersuchungen an Uredinales. Doctoral dissertation, Universität Tübingen, Tübingen, Federal Republic of Germany.

Bergdahl D.R. and French D.W., 1985 - Penetration of the primary tissues of Pinus banksiana by Cronartium comandrae. In: J. Barrows-Broaddus and H.R. Powers (Eds.). "Proceedings of I.U.F.R.O. Rusts of hard pines Conference”, pp. 179-192. Oct. 1984, Athens, Univ. Georgia.

Brundrett M.C., Kendrick B. and Peterson C.A., 1991 - Efficient lipid staining in plant material with Sudan Red $7 B$ or Fluorol-Yellow 088 in Polyetbylene Glicol-Glycerol. Biotechnic and Histochemistry: 111-116.

Bushnell W.R. and Roelfs A.P., 1984 - The cereal rusts. Vol. 1. Academic Press, Orlando.

Campbell R., 1972 - Electron microscopy of the epidermis and cuticle of the needles of Pinus nigra var. maritima in relation to infection by Lophodermella sulcigena. Annals of Botany, 36: 307-314.

Chassot C. and Métraux J.-P., 2005 - The cuticle as source of signals for plant defence. Plant Biosystems, 139(1): 28-31.

Diner A.M. and MotT R.L., 1982 - Direct inoculation of five-needled Pines with Cronartium ribicola in axenic culture. Phytopathology, 72: 1181-1184.

Epstein L. and Nicholson R., 1997 - Adhesion of spores and byphae to plant surfaces. In: G.C. CARRoL and P. Tudzynski (Eds.). "Plant Relationships”. The Mycota, Vol V, (part A), pp. 11-25. Springer, Berlin.

Esau K., 1965 - Plant anatomy. II Ed. John Wiley and Sons, Inc., New York, London, Sydney.

Gold R.E. and Mendgen K., 1984 - Cytology of basidiospore germination, penetration, and early coloniza- tion of Phaseolus vulgaris by Uromyces appendiculatus var. appendiculatus. Canadian Journal of Botany, 62: 1989-2002.

—, 1991 - Rust basidiospore germlings and disease initiation. In: G.T. Cole and H.C. Hoch (Eds.). "The fungal spore and disease initiation in plants and animals”, pp. 67-99. Plenum Press, New York.

Gray D.J., Amerson H.V. and Van Dyke C.G., 1983 - Ultrastructure of the infection and early colonization of Pinus taeda by Cronartium quercuum $f$. sp. fusiforme. Mycologia, 75: 117-130.

Greenspan P., Mayer E.P. and Fowlers S.D., 1985 - Nile red: a selective fluorescent stain for intracellular lipid droplets. Journal of Cell Biology, 100: 965-973.

Grill D., Lackner E. und Scharner M., 1978 - Untersuchungen an mit Chrysomyxa abietis befallenen Fichtennadeln. Phyton, 19: 71-82.

Hardham A.R., 2001 - Cell biology of fungal infection of plants. In: R.J. Howard and N.A.R. Gow (Eds.). "Biology of fungal cell". The Mycota, Vol. VIII, pp. 91-123. Springer, Berlin.

Heath M.C., 2002 - Cellular interactions between biotrophic fungal pathogens and host or nonhost plants. Canadian Journal of Plant Pathology, 24 (3): 259-264.

Hoch H.C. and Staples R.C., 1991 - Signaling for infection structure formation in fungi. In: G.T. Cole and H.C. Hoch (Eds.). "The fungal spore and disease initiation in plants and animals", pp. 25-46. Plenum Press, New York.

Hopkin A.A., Reid J., Hiratsuka Y. and Allen E., 1988 - Initial infection and early colonization of Pinus contorta by Endocronartium harknessii (western gall rust). Canadian Journal of Plant Pathology, 10: 221-227.

How ARD R.J., 1997 - Breaching the outer barriers. Cuticle and cell wall penetration. In: G.C. Carrol and P. Tudzynski (Eds.). "Plant Relationships". The Mycota, Vol V, (part A), pp. 43-60. Springer, Berlin.

Johansen D.A., 1940 - Plant microtechnique. McGraw-Hill Book Co. Inc., N.Y.

LitTlefield L.J. and Heath M.C., 1979. - Ultrastructure of the rust fungi. Academic Press, New York, S. Francisco, London.

Longo N., Moriondo F. and Naldini B., 1970 - Biologia ed epidemiologia di Melampsora pinitorqua Rostr. Annali dell'Accademia Italiana di Scienze Forestali, 19: 85-175.

Longo N., Moriondo F. and Naldini Longo B., 1975 - The status of Melampsora pinitorqua Rostr. in Italy. European Journal of Forest Pathology, 5: 147152.

Longo N., Naldini B., Drovandi F., Gonnelli T, and TANI G., 1994 - Penetration and early colonization in basidiospore-derived infection of Melampsora pulcherrima (Bub.) Maire on Mercurialis annua L. Caryologia, 47: 207-222.

Longo N., Naldini B., Paolillo A., Drovandi F., TAni G. and Gonnelli T., 1997 - Morphological aspects of early host-parasite interactions in infec- 
tions of Melampsora pinitorqua and Melampsora larici-tremulae on Pinus sylvestris. Implications in the taxonomical relationship of the two rust fungi. Caryologia, 50: 35-57.

Longo N., Naldini Longo B., Tani G. and Drovandi F., 1988 - Osservazioni sull'infezione basidiosporica di Melampsora pinitorqua Rostr. (Uredinales) in alcuni ospiti del gen. Pinus. Giornale Botanico Italiano, 122 (suppl. 1): 155.

-, 1991 - Penetration and early colonization in basidiospore-derived infection of Melampsora pinitorqua Rostr. on Pinus. Structural and ultrastructural observations. In: Y. Hiratsuka et al. (Eds.). "Rusts of Pine". Proceedings of I.U.F.R.O. Rusts of pine Conference, Sept. 1989, Banff, Alberta. Inf. Rep. Nor - X, 317: 120-127.

Longo N., Poggiolesi S., Naldini B. and Tani G., 2000 - Penetration and early colonization in basidiospore-derived infection on needles of Pinus pinea $L$. by Cronartium flaccidum (Alb. et Schw.) Wint. Caryologia, 53: 9-29.

Mendgen K., 1997 - The Uredinales. In: G.C. Carrol and P. Tudzynski (Eds.). "Plant Relationships". The Mycota, Vol V (part B), pp. 79-85. Springer, Berlin.

Mendgen K. and Deising H., 1993 - Infection structures of fungal plant pathogens - A cytological and physiological evaluation. New Phytologist, 124: 193 213.

Mendgen K., Hahn M. and Deising H., 1996 - Morphogenesis and mechanism of penetration by plant pathogenic fungi. Annual Review of Phytopathology, 34: 367-386.

Miller T., Patton R.F. and Powers H.N.Jn., 1980 - Mode of infection and early colonization of slash pine seedlings by Cronartium quercuum f. sp. fusiforme. Phytopathology, 70: 1206-1208.

Moricca S., Naldini B., Dellavalle I., Longo N. and Ragazzi A., 2003 - Basidiospore-derived penetrations in some species of Cronartium and Melampsora. An outline. Communication to International Symposium: "Melampsora Rusts of Salicaceae". 1012 Sept. 2003, Belfast, Ireland.

Morin L., Brown J.F. and Auld B.A., 1992 - Teliospore germination, basidiospore formation and the infection process of Puccinia xanthii on Xanthium occidentale. Mycological Research, 96: 661-669.

Napp-Zinn K., 1966 - Blattanatomie der Gimnospermen. In: W. Zimmermann, P. Ozenda and H.D. Wulff (Eds.). "Handbuch der Pflanzenanatomie", Vol. VIII (1). Gebruder Borntrager, Berlin, Nikolassee.

Patton R.F. and Johnson D.W., 1970 - Mode of penetration of needles of eastern white pine by Cronartium ribicola. Phytopathology, 60: 977-982.
Pryce-Jones E., Carver T. and Gurr S.J., 1999 The role of cellulase enzymes and mechanical force in host penetration by Erysiphe graminis f. sp. hordei. Physiological and Molecular Plant Pathology, 55: 175-182.

Ragazzi A. and Dellavalle Fedi I., 1992 - Penetration of Cronartium flaccidum into pine needles. European Journal of Forest Pathology, 22: 278-283.

Ragazzi A., Fagnani A. and Dellavalle Fedi I., 1987 - Telial and basidiospore stages of Cronartium flaccidum: light and scanning electron microscopy observations. Phytopathologia Mediterranea, 26: 81-84.

Ragazzi A., Longo N., Naldini B., Moricca S. and Dellavalle I., 2005 - Basidiospore-derived penetration by species of Cronartium and Melampsora: an outline. In: M.H. Pei and A.R. McCracken (Eds.). "Rust diseases of Willow and Poplar", pp. 161-174. CABI Publishing.

SMART M.G., 1991 - The plant cell wall as a barrier to fungal invasion. In: G.T. Cole and H.C. Hoch (Eds.). "The fungal spore and disease initiation in plants and animals", pp. 46-66. Plenum Press, New York.

Soukupová J., Cvikrová M., Albrechtová J., Rock B.N. and Eder J., 2000 - Histochemical and biochemical approaches to the study of phenolic compounds and peroxidase in needles of Norway spruce (Picea abies). New Phytologist, 146: 403-414.

Southerton S.G. and Deverall B.J., 1990 - Histochemical and chemical evidence for lignin accumulation during the expression of resistance to leaf rust fungi in wheat. Physiological and Molecular Plant Pathology, 36: 483-494.

Ten Have A., Tenberge K.B., Benen J.A.E., Tudzynski P., Visser J. and van Kan J.A.L., 2002 - The contribution of Cell Wall Degrading Enzymes to Pathogenesis of Fungal Plant Pathogens. In: F. Kempken (Ed.). "Agricultural Applications". The Mycota, Vol. XI, pp. 341-358. Springer, Berlin.

Trail F. and Koller W., 1990 - A role for cutinase in the expression of tissue specificity by fungal pathogens. Phytopathology, 80: 1055.

Wirsel S.G.R., Reiman S. and Deising H.B., $2004-$ Genetics of Phytopathology: Fungal Morphogenesis and Plant Infection. Progress in Botany, 65 (2003): 147-178.

Walton J.D., 1994 - Decostructing the cell wall. Plant Physiology, 104: 1113-1118.

Xu HaiXin., Mendgen K. and Xu H.X., 1997 - Targeted cell wall degradation at the penetration site of cowpea rust basidiosporelings. Molecular Plant Microbe Interaction, 10: 87-94.

Received 07.12.2005; accepted 25.03.2006 